\title{
Authentic leadership and organisational citizenship behaviour in the public health care sector: The role of workplace trust
}

\begin{tabular}{|c|c|}
\hline \multicolumn{2}{|c|}{ 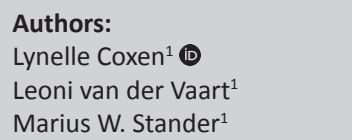 } \\
\hline \multicolumn{2}{|c|}{$\begin{array}{l}\text { Affiliations: } \\
{ }^{1} \text { Optentia Research Focus } \\
\text { Area, Department of } \\
\text { Industrial Psychology, } \\
\text { North-West University, Vaal } \\
\text { Triangle Campus, South Africa }\end{array}$} \\
\hline \multicolumn{2}{|c|}{$\begin{array}{l}\text { Corresponding author: } \\
\text { Lynelle Coxen, } \\
\text { lynellecoxen@yahoo.com }\end{array}$} \\
\hline \multicolumn{2}{|c|}{$\begin{array}{l}\text { Dates: } \\
\text { Received: } 12 \text { Apr. } 2016 \\
\text { Accepted: } 29 \text { Aug. } 2016 \\
\text { Published: } 24 \text { Oct. } 2016\end{array}$} \\
\hline \multicolumn{2}{|c|}{$\begin{array}{l}\text { How to cite this article: } \\
\text { Coxen, L., Van der Vaart, L., \& } \\
\text { Stander, M.W. (2016). } \\
\text { Authentic leadership and } \\
\text { organisational citizenship } \\
\text { behaviour in the public } \\
\text { health care sector: The role } \\
\text { of workplace trust. SA Journal } \\
\text { of Industrial Psychology/SA } \\
\text { Tydskrif vir Bedryfsielkunde, } \\
\text { 42(1), a1364. http://dx.doi. } \\
\text { org/10.4102/sajip.v42i1.1364 }\end{array}$} \\
\hline \multicolumn{2}{|c|}{$\begin{array}{l}\text { Copyright: } \\
\text { (c) 2016. The Authors. } \\
\text { Licensee: AOSIS. This work } \\
\text { is licensed under the } \\
\text { Creative Commons } \\
\text { Attribution License. }\end{array}$} \\
\hline \multicolumn{2}{|l|}{ Read online: } \\
\hline 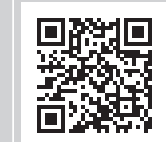 & $\begin{array}{l}\text { Scan this QR } \\
\text { code with your } \\
\text { smart phone or } \\
\text { mobile device } \\
\text { to read online. }\end{array}$ \\
\hline
\end{tabular}

Orientation: The orientation of this study was towards authentic leadership and its influence on workplace trust and organisational citizenship behaviour in the public health care sector.

Research purpose: The aim of this study was to investigate the influence of authentic leadership on organisational citizenship behaviour, through workplace trust among public health care employees in South Africa. The objective was to determine whether authentic leadership affects organisational citizenship behaviour through workplace trust (conceptualised as trust in the organisation, immediate supervisor and co-workers).

Motivation for the study: Employees in the public health care industry are currently being faced with a demanding work environment which includes a lack of trust in leadership. This necessitated the need to determine whether authentic leadership ultimately leads to extra-role behaviours via workplace trust in its three referents.

Research design, approach and method: A quantitative cross-sectional survey design was used with employees the public health care sector in South Africa $(N=633)$. The Authentic Leadership Inventory, Workplace Trust Survey and Organisational Citizenship Behaviour Scale were administered to these participants.

Main findings: The results indicated that authentic leadership has a significant influence on trust in all three referents, namely the organisation, the supervisor and co-workers. Both trust in the organisation and trust in co-workers positively influenced organisational citizenship behaviour. Conversely, authentic leadership did not have a significant influence on organisational citizenship behaviour. Finally, authentic leadership had a significant indirect effect on organisational citizenship behaviour through trust in the organisation and trust in co-workers. Trust in the organisation was found to have the strongest indirect effect on the relationship between authentic leadership and organisational citizenship behaviour.

Practical/managerial implications: The main findings suggest that public health care institutions would benefit if leaders are encouraged to be more authentic as this might result in increases in both trust among co-workers and in the organisation. Consequently, employees might be more likely to exert additional effort in their work.

Contribution/value-add: Limited empirical evidence exists with regard to the relationship between authentic leadership, workplace trust in its three referents and organisational citizenship behaviour. This study aimed to contribute to the limited number of studies conducted.

\section{Introduction}

One of the National Development Plan's (NDP) goals is to strengthen the South African health system by optimising human capital, improving quality care and enhancing effective leadership (National Planning Commission [NPC], 2011). The achievement of these goals can address some of the external and internal challenges that the public health care sector is currently facing. Some of the external challenges include service delivery inefficiencies and customer dissatisfaction (Health Systems Trust, 2013; Okanga \& Drotskie, 2015), which may be improved if public health care employees go the 'extra mile' in their work (Dash \& Pradhan, 2014). Internally, the public health care sector is challenged by poor management structures and a lack of trust in leadership (Benatar, 2013; George, Atujuna, \& Gow, 2013; Health Systems Trust, 2013). The Department of Health (DoH, 2011) has therefore included leadership as one of its pillars in the improvement of quality health care services. Authentic leadership may be of particular importance in this 
organisation. It can be regarded as a positive form of leadership (Avolio \& Gardner, 2005; Beddoes-Jones \& Swailes, 2015) that contributes to positive organisations which have a positive impact on employee and organisational behaviours (Zbierowski \& Góra, 2014).

The role of workplace trust as a mechanism through which leaders influence their subordinates, has received limited attention in South Africa, particularly in the public health care sector. Workplace trust can be considered as a consequence of authentic leadership (Clapp-Smith, Vogelsang, \& Avey, 2009; Datta, 2015; Errazquin, 2013) and a predecessor of organisational citizenship behaviour (Altuntas \& Baykal, 2010; Chen, Wang, Chang, \& Hu, 2008). Leaders are considered to be the primary influencers of their subordinates' behaviour (Avolio, Gardner, Walumbwa, Luthans, \& May, 2004), they can therefore influence subordinates to engage in extra-role behaviours, also known as organisational citizenship behaviour (Dash \& Pradhan, 2014).

Leadership influences organisational citizenship behaviour (Hsieh \& Wang, 2015), particularly through trust (Walumbwa, Christensen, \& Hailey, 2011). Du Plessis, Wakelin and Nel (2015) mention that if employees feel that they are trusted, they are more likely to go the 'extra mile' in their work. According to Heyns and Rothmann (2015), an employee's willingness to trust a leader is influenced by the character and actions of the leader. In this study, the focus was specifically on authentic leadership. Walumbwa, Avolio, Gardner, Wernsing and Peterson (2008) define authentic leadership as a form of leadership that focuses on 'positive psychological capacities and a positive ethical climate', fostering the four dimensions of authentic leadership (p. 1). Authentic leadership has been researched in many contexts (Onorato \& Zhu, 2014), specifically in a Western context (Avolio \& Walumbwa, 2014) and has been demonstrated to have a positive impact on organisations, teams and individuals (Avolio \& Walumbwa, 2014; Rego, Vitória, Magalhães, Ribeiro, \& Cunha, 2013). However, leadership behaviour that is effective in one context is not necessarily effective in another context and a one-size-fits-all approach cannot be used indiscriminately (Avolio \& Walumbwa, 2014). In line with this, the current study evaluates the influence of authentic leadership in this particular sector.

Despite the importance of authentic leadership, limited studies have been conducted in a South African context (Du Plessis, 2014; Stander, De Beer, \& Stander, 2015), particularly with organisational citizenship behaviour as outcome. Although Heyns and Rothmann (2015) recently conducted a study in the South African context with regard to leaders' influence on employee trust, there is still limited empirical evidence relating to the relationship between authentic leadership and workplace trust, specifically in the public health care sector in South Africa. This study focused on workplace trust in its three referents, including trust in the organisation, trust in the immediate supervisor and trust in co-workers to test the impact of perceived authentic leadership on organisational citizenship behaviour, both directly and indirectly.

\section{Literature review}

\section{Authentic leadership}

Several forms of leadership, including ethical, charismatic, servant, transactional and transformational leadership, have been studied in the past (e.g. Bass, 1990; Bass \& Avolio, 1993; Engelbrecht, Hein, \& Mahembe, 2014; Shamir, House, \& Arthur, 1993; Stone, Russell, \& Patterson, 2004). Recently, research has focused extensively on positive and ethical forms of leadership (Engelbrecht et al., 2014; Zbierowski \& Góra, 2014). Current research focuses on authentic leadership which is emphasised both in the academic field as well as in industry (Hsieh \& Wang, 2015; Men \& Stacks, 2014; Walumbwa et al., 2008). For the purpose of this study, authentic leadership was conceptualised as a higher order construct consisting of four lower order dimensions, namely self-awareness, balanced processing, relational transparency and internalised moral perspective (Walumbwa et al., 2008).

Self-awareness refers to the leader's ability to possess selfknowledge and to be aware of possible strengths, developmental areas and beliefs as well as the impact thereof on followers (Gardner, Cogliser, Davis, \& Dickens, 2011; Men \& Stacks, 2014). Balanced processing is defined as a leader's objective evaluation and analysis of relevant information when considering the opinions of others in decision-making (Gardner, Avolio, Luthans, May, \& Walumbwa, 2005; Walumbwa et al., 2008). The third dimension, relational transparency, refers to the leader's ability to openly share information and to present the self in an unpretentious manner (Stander et al., 2015). Lastly, an internalised moral perspective is defined as the leader's ability to withstand external pressures by committing to his or her own ethical and moral values (Gardner et al., 2011; Ryan \& Deci, 2003; Walumbwa et al., 2008). It should be noted that authentic leadership will be measured from the employees' perceptions with regard to the authenticity of their leaders.

Authentic leaders are perceived as leaders who show authenticity and are able to foster respect, credibility and, ultimately, trust among subordinates (Bamford, Wong, \& Laschinger, 2013). Avolio and Walumbwa (2014) and Stander et al. (2015) further mentioned that an authentic leader inspires and motivates subordinates and that the authentic leader possesses a strong interpersonal orientation. This relational nature encourages subordinates to be able to relate to the leader and organisation (Avolio \& Walumbwa, 2014). In addition, a stronger sense of identification is created among subordinates (Avolio \& Walumbwa, 2014). Accordingly, authentic leaders have a profound impact on their subordinates as well as the organisations for which they work (Pues, Wesche, Streicher, Braun, \& Frey, 2012). In their development of a three-pillar authentic leadership model, Beddoes-Jones and Swailes (2015) have found that trust is at the foundation of authentic leadership. Likewise, a study conducted by Avolio and Gardner (2005) found that the 
personal integrity of an authentic leader, as well as the leader's ability to engage in balanced processing might lead to leader-subordinate relationships that are characterised by respect and trust.

The Social Exchange Theory (SET; Blau, 1964) suggests that the actions of individuals depend on 'rewarding reactions' from others (Penger \& Cěrne, 2014, p. 511). The focus is thus on reciprocity. Leadership and trust can therefore be perceived as a social exchange between leaders and subordinates (Hsieh \& Wang, 2015).

\section{Workplace trust}

Workplace trust is conceptualised as the consistency between the perceptions of an individual with regard to a trust referent (organisation, immediate supervisor and co-worker) and the individual's subsequent actions (Ferres, 2003). These actions can include being supportive, competent and mindful of others' performance (Ferres \& Travaglione, 2003). The focus is on trust in its three referents, namely organisation, immediate supervisor and co-worker. Ferres (2003) operationalises trust in the organisation as openness when sharing information, fair organisational processes and a supportive work environment. Organisational trust is the trust that employees have in the organisation itself (James, 2011), which is influenced by their perceptions of the effectiveness of organisational processes and whether the organisation is perceived to be reliable and honest (Galford \& Drapeau, 2003). As leaders are seen as higher organisational authorities (Treviño \& Brown, 2004), they are regarded as representatives of the organisation (O'Reilly, Caldwell, Chatman, Lapiz, \& Self, 2010) and may influence the perceived trust that employees have in the organisation.

Trust in the immediate supervisor is operationalised as supervisors who listen when employees share information and who appreciate employees' additional efforts (Ferres, 2003; Ferres \& Travaglione, 2003). Consequently, James (2011) denotes that trust in the immediate supervisor transpires from fair treatment; when the needs of subordinates are considered during decision making. As authentic leaders are considered to act with integrity and have a sense of purpose while being cognisant of their core values (Hassan \& Ahmed, 2011), they are likely to gain the trust of their subordinates as a result of their genuineness and consistency in terms of words and actions (Hsieh \& Wang, 2015; Xiong \& Fang, 2014).

Trust in the co-worker is operationalised as collegial support, truthful interactions and appreciation for each other's work (Ferres, 2003). It can further be demarcated as having confidence in colleagues to be competent and act in a fair and ethical manner (James, 2011). Onorato and Zhu (2014) postulated that authentic leaders succeed in creating a positive and ethical organisational climate that is characterised by openness, transparency and communication (Mazutis \& Slawinski, 2007). This leader is regarded as a role model (Khan, 2010), able to facilitate authenticity among subordinates (Avolio \& Gardner, 2005; Avolio et al., 2004).
Although Schoeman (2012) studied the role of trust in its three referents, there are still limited studies that emphasise all three referents in the South African context, specifically with authentic leadership as antecedent and organisational citizenship behaviour as outcome. Schoeman (2012) focused on determining whether trust in its three referents correlates with psychological capital (PsyCap) and workplace wellbeing. Other South African studies (e.g. Du Plessis et al., 2015; Stander et al., 2015) that included trust as a construct, focused on trust in only one or two referents and not in all three referents. Du Plessis et al. (2015) focused only on trust in the immediate supervisor, whereas Stander et al. (2015) emphasised trust in the organisation. The focus on all three trust referents is important as it can guide future interventions and provide the organisation with an indication on how to structure and prioritise interventions, if they understand which referent mostly affects employees.

Similar to the relationship between authentic leadership and workplace trust, the relationship between trust and organisational citizenship behaviour can also be studied from a SET perspective. For example, employees who trust their organisation, supervisors and/or co-workers are more likely to exert extra effort in their work.

\section{Organisational citizenship behaviour}

Organ (1997) defined organisational citizenship behaviour as the determined and unrestricted behaviour of employees which contributes to the organisation's effectiveness and functioning. In addition, Bester, Stander and Van Zyl (2015) stated that instead of being a formal requirement, organisational citizenship behaviour is employees' personal choice. For the purpose of this study, organisational citizenship is conceptualised as consisting of two dimensions, an interpersonal orientation and an organisational orientation (Diedericks, 2012). Interpersonal orientation refers to employees' willingness to provide assistance to co-workers, whereas the organisational orientation refers to the employees' willingness to exert additional effort on behalf of the organisation (Organ \& Paine, 1999; Rothmann, 2010).

In their study, Al-Sharafi and Rajiani (2013) have confirmed that effective leadership can be regarded as an antecedent of organisational citizenship behaviour. Pues et al. (2012) have found that authentic leadership can be seen as a predictor of organisational citizenship behaviour. They regarded organisational citizenship behaviour from a supervisorrated perspective (Pues et al., 2012), instead of focusing on employees' perceptions of their own organisational citizenship behaviours. The focus on employee perceptions is important to understand how the employee views and/or feels about the situation.

Another theoretical framework that supports the hypothesised relationship between authentic leadership and organisational citizenship behaviour is the Job-Demands Resources (JD-R) model (Bakker, Demerouti, De Boer, \& Schaufeli, 2003; Demerouti, Bakker, Nachreiner, \& Schaufeli, 2001). For the 
purpose of this study, authentic leadership was classified as a job resource and organisational citizenship behaviour as a behavioural outcome.

\section{The indirect effect of workplace trust}

Trust is regarded as a predictor of organisational citizenship behaviour (Wong, Wong, \& Ngo, 2012) and may potentially affect the relationship between authentic leadership and organisational citizenship behaviour. According to Dannhauser (2007), trust can act as a causal, mediating, moderating, or outcome variable in an organisational setting. Wong et al. (2012) mentioned that trust emerges through a continued exchange of benefits between parties, which in turn influences the work outcomes of employees. Many studies have used trust as a mediator, but not in all three its referents (e.g. Du Plessis et al., 2015; Halbesleben \& Wheeler, 2012). Studies have found that supervisor trust plays a mediating role in contributing to both organisational citizenship behaviour and work engagement with authentic leadership as predictor (Altuntas \& Baykal, 2010; Hsieh \& Wang, 2015). Another study found that organisational and supervisor trust mediates the relationship between justice and organisational citizenship behaviour, but the mediational impact of the two referents differs (Aryee, Budhwar, \& Chen, 2002).

Most authors focused on trust in the immediate supervisor and/or leader (e.g. Du Plessis et al., 2015; Engelbrecht et al., 2014). Stander et al. (2015) specifically focused on trust in the organisation, whereas Schlechter and Strauss (2008) studied both trust in the immediate supervisor and trust in coworkers. Recent studies on trust either focused on one referent of trust (e.g. Hsieh \& Wang, 2015; supervisor trust), two referents of trust (e.g. Paliszkiewicz, Koohang, \& Nord, 2014; organisational and supervisor trust), or three referents on trust (e.g. Cho \& Park, 2011; trust in the organisation, trust in the immediate supervisor and trust in co-workers). These studies, with the exception of the study of Cho and Park (2011), did not attempt to determine the strength of the indirect effects of the different trust referents. The study by Cho and Park (2011) aimed to determine whether trust in its three referents mediates the relationship between managerial practices and employee attitudes of commitment and satisfaction. In this study, it is vital to determine how employees' perceptions of authentic leadership influence organisational citizenship behaviour through the three referents of trust, as this relationship has not been empirically tested to date in this organisation.

Based on the above discussion, the aims and hypotheses of the study were outlined as follows:

Hypothesis 1: Authentic leadership is a significant predictor of workplace trust.

Hypothesis 2: Workplace trust is a significant predictor of organisational citizenship behaviour.

Hypothesis 3: Authentic leadership is a significant predictor of organisational citizenship behaviour.
Hypothesis 4: Authentic leadership has an indirect effect on organisational citizenship behaviour through workplace trust.

Hypothesis 5: There are differences in the strength of the indirect effects of different workplace trust referents.

The hypothesised model is illustrated in Figure 1.

\section{Research design Research approach}

For the purpose of this study, a quantitative research approach was used with a cross-sectional survey design.

\section{Research method}

\section{Research participants}

A non-probability sampling method was used. Specifically, convenience sampling was used as the participants were selected on the basis of their accessibility. The sample - out of a population of approximately 2000 - consisted of 633 employees working in the public health care sector. The sample was drawn from 27 hospitals and/or clinics and the participants had a mean age of 42.44 years $(\mathrm{SD}=12.27)$. The majority of the sample consisted of females (79.6\%), and the most representative home language was Sesotho (44.7\%), followed by isiZulu (19.2\%). The majority of the participants were black $(87.9 \%)$, and $38.5 \%$ of the sample possessed a diploma and/or tertiary certificate. In addition, $40.3 \%$ of the sample has been working for the organisation for less than 5 years, with $34.1 \%$ working for the organisation for more than 15 years. Finally, $47.7 \%$ of employees have been working in their current position for less than 5 years. In terms of function, the majority of the sample indicated other (50.9\%), followed by administration (19.6\%), management $(17.4 \%)$ and specialist $(12.0 \%)$.

\section{Measuring instruments}

A biographical questionnaire as well as three measuring instruments was used to measure the constructs of authentic leadership, workplace trust and organisational citizenship behaviour.

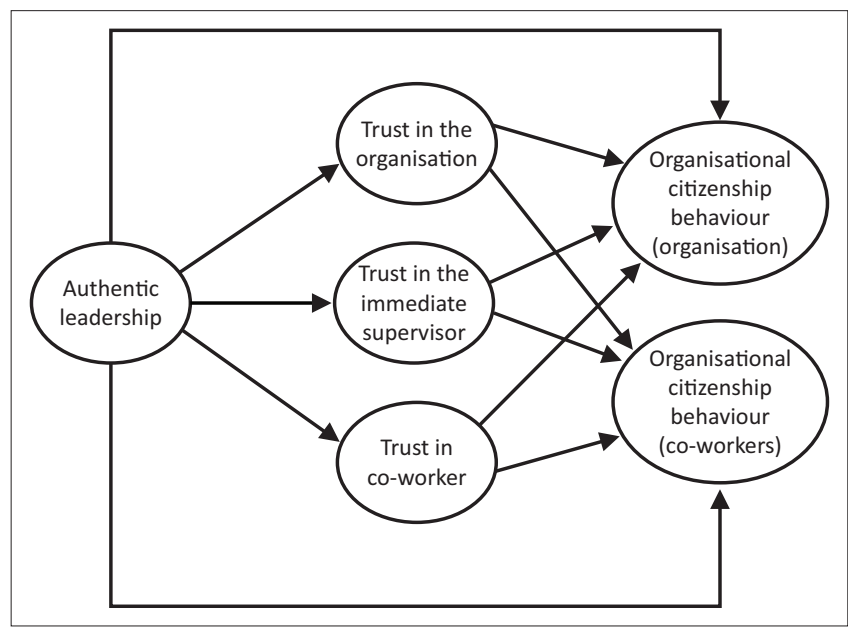

FIGURE 1: A hypothesised model of authentic leadership and organisational citizenship behaviour with the indirect effects of workplace trust. 
Biographical questionnaire: A biographical questionnaire was used to gain information regarding the demographic characteristics of the participants.

Authentic Leadership Inventory: The Authentic Leadership Inventory (ALI) was used to determine subordinates' perceptions regarding the authenticity of their leaders (Neider \& Schriesheim, 2011). The four dimensions of authentic leadership, namely self-awareness, balanced processing, relational transparency and internalised moral perspective were used to measure the perceptions of these employees. The ALI measures the same dimensions as the Authentic Leadership Questionnaire (ALQ) developed by Walumbwa et al. (2008). Neider and Schriesheim (2011) developed the ALI as they were concerned about the subjective content analysis of the ALQ and the 'garbage parameters' used to improve model fit. The ALI contains fourteen items where response options are arranged on a 5-point Likert-type scale ranging from 1 (strongly disagree) to 5 (strongly agree). Example items of the ALI include: 'My leader carefully listens to alternative perspectives before reaching a conclusion' and 'My leader uses his and/or her core beliefs to make decisions'. Previous studies found acceptable reliabilities with Cronbach's alpha coefficients ranging between 0.74 and 0.90 (Men \& Stacks, 2014; Neider \& Schriesheim, 2011).

Workplace Trust Survey: The Workplace Trust Survey (WTS) was used to measure trust in the organisation, trust in the immediate supervisor, as well as trust in co-workers (Ferres, 2003). It consists of 32 items, with 11 items related to trust in the organisation, 9 items related to supervisor trust and 12 items related to trust in co-workers. Items were scored using a 4-point Likert-type scale which ranged from 1 (strongly disagree) to 4 (strongly agree). Example items include: 'I feel that information can be shared openly within my organisation' (organisation); 'I feel that my supervisor keeps personal discussions confidential' (supervisor); and 'I think that my co-workers act reliably from one moment to the next' (co-workers). According to Ferres and Travaglione (2003), the internal consistency of the items yielded acceptable reliabilities, with Cronbach's alpha coefficients: $\alpha=0.95$ (organisation); $\alpha=0.96$ (immediate supervisor); and $\alpha=0.93$ (co-workers).

Organisational Citizenship Behaviour Scale: The Organisational Citizenship Behaviour Scale (OCBS) was used to measure employees' organisational citizenship behaviour (Rothmann, 2010). The OCBS contains six items with three items relating to the assistance to co-workers subscale and three items measuring the organisational assistance subscale. A 6-point Likert-type scale which ranged from 1 (strongly disagree) to 6 (strongly agree) was used. Example items contained in the scale include 'I show genuine concern and courtesy toward co-workers, even under the most trying business or personal situations' (co-worker assistance) and 'I defend the organisation when other employees criticize it' (organisational assistance). According to Diedericks (2012), both the dimensions yielded acceptable reliabilities, with assistance to co-workers $(\alpha=0.78)$ and assistance to the organisation $(\alpha=0.80)$.

\section{Research procedure and ethical considerations}

The data were collected as part of a larger project focusing on work-related well-being in the public health care sector. The research was conducted in a fair and ethical manner and participation was voluntary. The questionnaires were distributed at the hospitals and/or clinics, once the questionnaires had been completed participants were required to return the completed questionnaires. The study was approved by the North-West University's ethics committee, HHREC.

\section{Statistical analysis}

Mplus 7.31 (Muthén \& Muthén, 1998-2012) and SPSS 22 (IBM Corporation, 2013) were used to analyse the data in the study. Structural equation modelling (SEM), more specifically, a two-step model generating approach, also referred to as latent variable modelling, was used (Kline, 2011). Firstly, confirmatory factor analyses (CFA) were performed to determine the factor structure of the constructs. The structural model was then estimated by means of inserting the hypothesised regression paths.

The model's fit to the data was determined by the following parameter estimates and indices (Byrne, 2012): Chi-square $\left(\chi^{2}\right)$, degrees of freedom $(d f)$, root mean square error of approximation (RMSEA; smaller than 0.08 indicates acceptable fit), TuckerLewis Index (TLI) and the index of choice, comparative fit index (CFI) (Byrne, 2012; Hair, Babin, Black, \& Andersen, 2010). CFI and TLI values higher than 0.95 show acceptable fit (Hu \& Bentler, 1999). Additionally, two fit statistics referred to as the Akaike Information Criterion (AIC) and the Bayes Information Criterion (BIC) were utilised to compare different measurement and structural models. For both these fit statistics, a lower value indicates better fit (Hair et al., 2010). A Maximum Likelihood Robust Estimator (MLR), which is appropriate for data that is not normally distributed and small to medium sample sizes (Kelloway, 2015), was employed.

The reliability for each scale was computed using composite reliability coefficients ( $\rho$ ) (Raykov, 2009) with a cut-off point of 0.70 (Wang \& Wang, 2012). Based on the best-fitting structural model, the potential indirect effects of workplace trust were inserted. Indirect effects of workplace trust were determined by bootstrapping and the construction of bias-corrected 95\% confidence intervals (CIs) (Mokgele \& Rothmann, 2014). The practical significance of the indirect effects was tested by means of the kappa-squared $\left(K^{2}\right)$ effect sizes to determine a small (below 0.09), medium (between 0.09 and 0.25), or large effect (above 0.25), respectively (Preacher \& Kelley, 2011).

\section{Results}

\section{Confirmatory factor analysis for the measuring instruments}

According to its authors, authentic leadership was specified as a four-factor structure (Neider \& Schriesheim, 2011), workplace trust as a three-factor structure (Ferres, 2003) and organisational citizenship behaviour as a two-factor structure (Rothmann, 2010). Based on the fit indices in Table 1, the hypothesised 
TABLE 1: Changes in the fit statistics in confirmatory factor analyses of authentic leadership, workplace trust and organisational citizenship behaviour.

\begin{tabular}{|c|c|c|c|c|c|c|c|c|c|c|}
\hline \multirow[t]{2}{*}{ Variable } & \multicolumn{2}{|c|}{$\chi^{2}$} & \multicolumn{2}{|c|}{$d f$} & \multicolumn{2}{|c|}{ CFI } & \multicolumn{2}{|c|}{ TLI } & \multicolumn{2}{|c|}{ RMSEA } \\
\hline & Author & Re-specified & Author & Re-specified & Author & Re-specified & Author & Re-specified & Author & Re-specified \\
\hline Authentic leadership & 426.94 & 73.59 & 71 & 26 & 0.89 & 0.98 & 0.86 & 0.97 & 0.09 & 0.05 \\
\hline Workplace trust & 1612.84 & 442.16 & 461 & 203 & 0.86 & 0.96 & 0.85 & 0.95 & 0.06 & 0.04 \\
\hline $\begin{array}{l}\text { Organisational } \\
\text { citizenship behaviour }\end{array}$ & 102.5 & 10.64 & 8 & 4 & 0.87 & 0.99 & 0.75 & 0.97 & 0.14 & 0.05 \\
\hline
\end{tabular}

$\chi^{2}$, chi-square statistic; $d f$, degree of freedom; CFI, comparative fit Index; TLI, Tucker-Lewis Index; RMSEA, root mean square error of approximation.

TABLE 2: Fit statistics of competing measurement models.

\begin{tabular}{|c|c|c|c|c|c|c|c|}
\hline Model & $\chi^{2}$ & $d f$ & CFI & TLI & RMSEA & AIC & BIC \\
\hline Model 1 & 1074.64 & 581 & 0.95 & 0.95 & $0.04[0.033,0.040]$ & 57657.89 & 58194.66 \\
\hline Model 2 & 1944.96 & 588 & 0.86 & 0.85 & $0.06[0.058,0.064]$ & 58737.09 & 59242.81 \\
\hline Model 3 & 1485.58 & 585 & 0.91 & 0.9 & $0.05[0.047,0.053]$ & 58168.09 & 58687.12 \\
\hline
\end{tabular}

$\chi^{2}$, chi-square statistic; $d f$, degree of freedom; CFI, comparative fit Index; TLI, Tucker-Lewis Index; RMSEA, root mean square error of approximation; AIC, Akaike Information Criterion; BIC, Bayes Information Criterion.

TABLE 3: Difference testing for changes in chi-square in competing measurement models.

\begin{tabular}{lccc}
\hline Model & D S-B $\chi^{2}$ & D $\Delta d f$ & $p$-value \\
\hline Model 1 versus Model 2 & 557.97 & 7 & $0.00^{*}$ \\
Model 1 versus Model 3 & 233.78 & 4 & $0.00^{*}$ \\
\hline
\end{tabular}

S-B, Satorra-Bentler; $\chi^{2}$, chi-square statistic; $d f$, degree of freedom. $* p<0.01$.

measurement model and factor structures yielded poor fit once specified using Mplus. For subsequent analyses, it was decided to specify authentic leadership as a one-factor structure which is in line with a South African study where a one-factor structure yielded good fit (Maximo, 2015). Organisational citizenship behaviour was also re-specified as a one-factor structure which corresponds with Beal III, Stavros and Cole's (2013) study. Workplace trust remained a three-factor model. Table 1 contains the changes in the fit indices of the re-specified models compared to the models of the original authors. The re-specified models indicate good fit as the cut-off values of CFI $(>0.95)$, TLI $(>0.95)$ and RMSEA $(\leq 0.08)$ were reached.

To improve model fit, certain items from the measuring instruments were deleted, error variances of some items were correlated and the latent variables' factor structures were respecified in Mplus. Deletion of items is performed based on the requirements stipulated by Wang and Wang (2012): (1) statistical, reflected in high MI values; and (2) theoretical, overlap in item content. A possible explanation behind the poor fit might be that some of the measuring instruments have not been validated or standardised in a South African context, making it difficult to apply the original factor structures and perceptions of meaning directly to a South African sample. This problem can be addressed by validating the instruments for South African use. The measurement model was thus specified with 9 items measuring authentic leadership, 5 items measuring organisational citizenship behaviour and 22 items measuring workplace trust. More specifically, trust in the organisation consisted of six items, trust in immediate supervisor of nine items and trust in co-workers of seven items.

\section{Testing measurement models}

Using SEM, a five-factor measurement model as well as two alternative models was tested to determine which measurement model fitted the data best. Model 1 consisted of five first-order latent variables, namely: (1) authentic leadership (measured by nine observed indicators); (2) trust in the organisation (measured by six observed indicators); (3) trust in the immediate supervisor (measured by nine observed indicators); (4) trust in co-workers (measured by seven observed indicators); and finally, (5) organisational citizenship behaviour (measured by five observed indicators). All the latent variables specified in Model 1 were allowed to correlate.

Model 2 was specified with 22 observed indicators measuring workplace trust as a one-factor structure. Both authentic leadership (nine observed indicators) and organisational citizenship behaviour (five observed indicators) were also specified as a one-factor structure. Finally, Model 3 was specified with workplace trust as a two-factor structure which included: a) Trust in the organisation and immediate supervisor (measured by 15 observed indicators); and b) trust in co-worker (measured by seven observed indicators). Schoeman (2012) used workplace trust as a two-factor structure, combining trust in the immediate supervisor and trust in the organisation as one factor and trust in co-worker as the second factor. Similar to Models 1 and 2, authentic leadership and organisational citizenship behaviour were specified as one-factor structures.

The fit statistics of the measurement model and its competing measurement models are presented in Table 2. Model 1 fitted the data best as determined by comparing the AIC and BIC values (the lower the value, the better the fit). Other fit indices were also considered to determine the models' fit to the data, including but not limited to the chi-square, CFI, TLI and RMSEA. According to $\mathrm{Hu}$ and Bentler (1999), these values indicate a good fit of the model to the data as CFI and TLI were equal to or higher than 0.95, and RMSEA was lower than 0.08 at 0.05 . The standardised coefficients of items ranged from 0.57 to 0.83 and were found to be statistically significant. This means that the items loaded significantly onto the specified factors without cross-loading occurring.

As indicated in Table 3, difference testing for changes in the robust $\chi^{2}$ in terms of the competing measurement models was conducted. Because of the use of the MLR-estimator, change in chi-square values cannot be directly compared and 
TABLE 4: Correlation matrix including reliabilities, means and standard deviations.

\begin{tabular}{|c|c|c|c|c|c|c|c|c|}
\hline Number & Variable & M & SD & $p$-value & 1 & 2 & 3 & 4 \\
\hline 1 & Authentic leadership & 3.37 & 0.92 & 0.92 & - & - & - & - \\
\hline 2 & Workplace trust: Organisation & 3.14 & 0.88 & 0.87 & $0.60 *$ & - & - & - \\
\hline 3 & Workplace trust: Supervisor & 3.52 & 0.89 & 0.92 & $0.82 t^{*}$ & $0.75 \dagger^{*}$ & - & - \\
\hline 4 & Workplace trust: Co-workers & 3.54 & 0.74 & 0.87 & $0.48 \dagger^{*}$ & $0.70 \div *$ & $0.71 *^{*}$ & - \\
\hline 5 & Organisational citizenship behaviour & 3.44 & 1.04 & 0.78 & $0.29 *$ & $0.42 \dagger^{*}$ & $0.34 \dagger^{*}$ & $0.41 \dagger^{*}$ \\
\hline
\end{tabular}

$\mathrm{M}$, mean; SD, standard deviation; $\rho$, composite reliability coefficient

Note: For statistical significance: ${ }^{*}, p<0.05 ; * *, p<0.01$. For practical significance: $\dagger, r>0.30$ and $\ddagger, r>0.50$.

Satorra-Bentler difference testing was performed (Satorra \& Bentler, 1999). Results in Table 4 indicate that Model 1 fitted the data significantly better than the competing models when comparing change in chi-square values.

\section{Testing the structural model}

Table 4 contains descriptive statistics, the reliability coefficients and correlations between the constructs. The composite reliability coefficients range from 0.78 to 0.92 , indicating acceptable reliability according to Wang and Wang's (2012) cut-off value of 0.70 . The composite reliabilities $(\rho)$ for the ALI and the OCBS were 0.92 and 0.73 , respectively. The composite reliabilities $(\rho)$ of the three subscales of WTS in the present study were: 0.87 (trust in the organisation), 0.88 (trust in the immediate supervisor) and 0.87 (trust in co-worker). The relationships between all the variables were statistically $(p<$ 0.01 ) and practically significant with either a small, medium or large effect. According to the results in Table 4, all variables were significantly and positively related to organisational citizenship behaviour - ranging between 0.29 and 0.42 . Authentic leadership was also positively and significantly related to the three referents of trust $(r=0.48$ to $r=0.82)$.

Based on the fact that the data were cross-sectional in nature, two other models were tested. Model 2 (also known as the direct pathways only model) did not meet the required cutoff values. However, Model 3 (known as the direct and indirect pathways model) also showed acceptable fit to the data with: robust $\chi^{2}=1074.64, d f=581, \mathrm{CFI}=0.95, \mathrm{TLI}=0.95$ and RMSEA $=0.04,95 \%$ CI [0.033, 0.040]. Model 1's fit was slightly better than Model 3's with lower BIC and AIC values. Although Model 1 showed the best fit, it differed from the hypothesised model.

Table 5 indicates the difference testing for changes in the robust $\chi^{2}$ with regard to competing structural models. The results show that Model 3 fitted the data significantly better than Model 2 after Satorra-Bentler difference testing had been performed. Model 1 fitted the data marginally better than Model 3 with a S-B $\chi^{2}=1.83(d f=1)$, resulting in a nonsignificant change. Since Model 1 fitted the data better it was decided to carry on with the analyses using this model.

The measurement model formed the basis for the structural models and latent variable modelling was used to test the direction of the hypothesised relationships. Table 6 displays the standardised path coefficients estimated for the
TABLE 5: Difference testing for changes in chi-square in competing structural models.

\begin{tabular}{lccc}
\hline Model & D S-B $\chi^{2}$ & D $\Delta d f$ & $p$-value \\
\hline Model 3 vs Model 2 & 305.18 & 3 & $0.00^{*}$ \\
Model 3 vs Model 1 & 1.83 & 1 & 0.18 \\
\hline
\end{tabular}

S-B, Satorra-Bentler; $\chi^{2}$, chi-square statistic; $d f$, degree of freedom. $*, p<0.01$.

competing structural models. Three structural models were tested and both Model 1 (indirect pathways) and Model 3 (direct and indirect pathways) showed a good fit to the data. However, Model 1 fitted the data best with the lowest AIC and BIC values, as well as a non-significant change in chisquare. This model included paths from authentic leadership to trust in the organisation, trust in the immediate supervisor and trust in co-workers, respectively. Paths from workplace trust divided in its three referents to organisational citizenship behaviour were also included. Based on this model, authentic leadership was found to be a significant predictor of trust in the organisation $(\beta=0.60, p<0.01)$, trust in the immediate supervisor $(\beta=0.82, p<0.01)$ and trust in co-workers $(\beta=0.48$, $p<0.01$ ). Hypothesis 1 was therefore accepted as authentic leadership was found to be a significant predictor of workplace trust in all three referents respectively.

Additionally, both trust in the organisation $(\beta=0.28, p<0.01)$ and trust in co-workers $(\beta=0.22, p<0.05)$ were significant predictors of organisational citizenship behaviour and had the anticipated positive direction. Trust in the immediate supervisor was not a significant predictor of organisational citizenship behaviour $(\beta=-0.02, p=0.81)$. Hypothesis 2 was only partially accepted as only trust in the organisation and co-workers significantly influenced organisational citizenship behaviour. Authentic leadership was not found to be a significant predictor of organisational citizenship behaviour. The third hypothesis, which states that authentic leadership is a significant predictor of organisational citizenship behaviour, was rejected.

Figure 2 shows the standardised path coefficients that were estimated for the best-fitting model. This figure only illustrates regression paths and the correlations that were permitted among workplace trust in its three referents.

From Figure 2, it is evident that $36 \%$ of the variance in trust in the organisation could be explained by authentic leadership. Additionally, authentic leadership explained $67 \%$ of the variance in trust in the immediate supervisor and $23 \%$ 
TABLE 6: Initial framework fit indices and standardised path coefficients.

\begin{tabular}{|c|c|c|c|c|}
\hline \multirow[t]{2}{*}{ Variable } & \multirow[t]{2}{*}{ Measures } & \multicolumn{3}{|c|}{ Pathways } \\
\hline & & Indirect (Model 1) & Direct (Model 2) & Direct and indirect (Model 3) \\
\hline \multirow[t]{8}{*}{ Fit indices } & $\chi^{2}$ & - & - & - \\
\hline & $d f$ & 582 & 584 & 581 \\
\hline & $\mathrm{CFI}$ & 0.95 & 0.91 & 0.95 \\
\hline & TLI & 0.95 & 0.9 & 0.95 \\
\hline & RMSEA & 0.04 & 0.05 & 0.04 \\
\hline & $95 \% \mathrm{Cl}$ & {$[0.03,0.04]$} & {$[0.05,0.053]$} & {$[0.03,0.04]$} \\
\hline & AIC & 57657.69 & 58189.68 & 57657.89 \\
\hline & $\mathrm{BIC}$ & 58190.03 & 58713.14 & 58194.66 \\
\hline \multirow{4}{*}{$\begin{array}{l}\text { Direct effects on organisational citizenship } \\
\text { behaviour }\end{array}$} & Authentic leadership & - & 0.09 & 0.13 \\
\hline & Workplace trust: Organisation & $0.28 * *$ & $0.29 * *$ & $0.28 * *$ \\
\hline & Workplace trust: Supervisor & -0.02 & -0.12 & -0.16 \\
\hline & Workplace trust: Co-workers & $0.22 *$ & $0.26 * *$ & $0.27 * *$ \\
\hline Direct effects on workplace trust: Organisation & Authentic leadership & $0.60 * *$ & - & $0.60 * *$ \\
\hline Direct effects on workplace trust: Co-workers & Authentic leadership & $0.48 * *$ & - & $0.48 * *$ \\
\hline
\end{tabular}

$\chi^{2}$, chi-square statistic; $d f$, degree of freedom; CFI, comparative fit Index; TLI, Tucker-Lewis Index; RMSEA, root mean square error of approximation; Cl, confidence intervals; AIC, Akaike Information Criterion; BIC, Bayes Information Criterion.

$*, p<0.05 ; * *, p<0.01$.

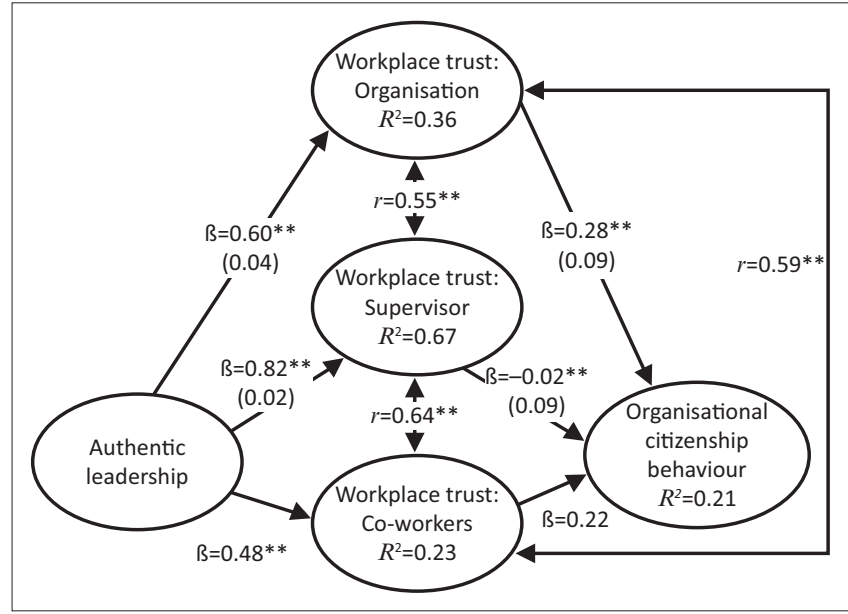

FIGURE 2: The best-fitting structural model.

in trust in co-workers. Finally, $21 \%$ of the variance in organisational citizenship behaviour was explained by authentic leadership as well as the three referents of trust.

\section{Indirect effects of workplace trust}

To determine whether any relationships in the model were affected by workplace trust, bootstrapping (with 5000 samples) was used. Two-sided bias-corrected 95\% CIs were constructed to evaluate indirect effects. Table 7 indicates the lower and upper CIs, as well as the estimates and standard errors of the tested indirect effects. From the Table, it is evident that authentic leadership had a significant indirect effect on organisational citizenship behaviour through trust in the organisation $(\beta=0.17, p<0.01,95 \% \mathrm{CI}[0.06,0.29])$ and trust in co-workers $(\beta=0.11, p<0.05,95 \%$ CI $[0.02,0.20])$. Hypothesis 4 was therefore partially accepted as only two referents of trust influenced the relation between authentic leadership and organisational citizenship behaviour indirectly.

Based on the results in Table 7 , it is evident that trust in the organisation $\left(\beta=0.17, p<0.01, K^{2}=0.21\right)$ had a greater indirect effect (medium) than trust in co-workers $(\beta=0.11$, $p<0.05, K^{2}=0.14$ ) with a small effect. Trust in the immediate supervisor did not significantly indirectly affect organisational citizenship behaviour $\left(\beta=-0.02, K^{2}=0.02\right)$ and therefore had a negligibly small effect. Hypothesis 5, focusing on the differences in the strength of the indirect effects of different trust referents, could therefore be supported.

\section{Discussion}

The aim of this study was to explore the influence of authentic leadership through workplace trust (conceptualised as trust in the organisation, immediate supervisor and co-workers) and organisational citizenship behaviour in the public health care sector. This was done to provide an understanding of how authentic leadership can evoke a more trusting workforce, resulting in employees going the 'extra mile'. This is specifically relevant in the South African public health care sector which is being challenged by service delivery difficulties, a lack of resources and trying working conditions characterised by work overload and a distrust in leadership (Barnard \& Simbhoo, 2014; Christian \& Crisp, 2012; George et al., 2013).

The structural model indicated that authentic leadership positively influenced workplace trust in its three referents. In this regard, leaders who are perceived as being objective, authentic, sharing information with others and listening to subordinates' ideas (Neider \& Schriesheim, 2011) are more likely to encourage trust in the organisation, supervisors and co-workers. The rationale behind this is that authentic leaders are perceived to be trustworthy, genuine and reliable (Avolio \& Gardner, 2005; Ilies, Morgeson, \& Nahrgang, 2005).

Cho and Park (2011) emphasise that the Leader-Member Exchange (LMX) theory regards trust in the supervisor as an important indicator focusing on the quality of the relationship between a leader and/or supervisor and/or manager and followers. Leaders who are perceived to be genuine and open 
TABLE 7: Indirect effects of authentic leadership.

\begin{tabular}{|c|c|c|c|c|c|c|c|c|c|}
\hline \multirow[t]{3}{*}{ Variable } & \multicolumn{9}{|c|}{ Workplace trust } \\
\hline & \multicolumn{3}{|c|}{ Organisation } & \multicolumn{3}{|c|}{ Supervisor } & \multicolumn{3}{|c|}{ Co-workers } \\
\hline & Est. & SE & $95 \% \mathrm{Cl}$ & Est. & SE & $95 \% \mathrm{Cl}$ & Est. & SE & $95 \% \mathrm{Cl}$ \\
\hline $\begin{array}{l}\text { Organisational } \\
\text { citizenship } \\
\text { behaviour }\end{array}$ & $0.17 * *$ & 0.06 & {$[0.06,0.29]$} & -0.02 & 0.07 & {$[-0.16,0.13]$} & $0.11 *$ & 0.05 & {$[0.02,0.20]$} \\
\hline
\end{tabular}

Est., Estimate; $\mathrm{SE}$, standard error; $\mathrm{Cl}$, confidence interval.

$*, p<0.05 ; * *, p<0.01$.

in expressing their feelings might encourage a climate where people will be willing to admit their mistakes and to challenge co-workers and/or managers to enhance performance. As a result, employees might be prone to regard the organisation and its management structures as effective and supportive. It is probable that authentic leaders could succeed in creating a positive and ethical organisational climate, characterised by openness and transparency which might facilitate trust among employees (Avolio et al., 2004). This climate can encourage employees to have confidence in their colleagues to be competent, fair and ethical. According to Lencioni (2005), when employees trust one another, they are more comfortable to being open about their growth areas and fears.

These findings are in line with previous studies that found a positive relationship between authentic leadership practices and workplace trust (e.g. Dannhauser, 2007; Engelbrecht et al., 2014; Errazquin, 2013; Hartog, Shippers, \& Koopman, 2002; Stander et al., 2015; Wang \& Hsieh, 2013). Other authors have also consistently linked authenticity in leaders to trust behaviours (Harter, Schmidt, \& Keys, 2003; Wong, Laschinger, \& Cummings, 2010). Studies also found a positive influence of authentic leadership on trust in the supervisor (ClappSmith et al., 2009; Errazquin, 2013; Hassan \& Ahmed, 2011). Heyns and Rothmann (2015) determined that when leaders are perceived as being trustworthy, followers are likely to reciprocate by engaging in trusting behaviours. Subordinates' perceptions of their leaders as a role model may evoke trust in co-workers.

Further results showed that both trust in the organisation and trust in co-workers significantly influenced organisational citizenship behaviour. These findings indicate that when employees work in an environment that they perceive as being supportive, fair, reliable and where others are mindful in recognising their performance and abilities, they will be more likely to go beyond what is formally expected of them - irrespective of whether they are doing it for their co-workers or for the organisation itself. Numerous studies have found a significant relation between trust in the organisation and organisational citizenship behaviour (Aryee et al., 2002; Dar, 2010; Schoeman, 2012; Wong et al., 2012).

Trust among co-workers can facilitate interpersonal helping behaviours (Cho \& Park, 2011), which may be regarded as a form of organisational citizenship behaviour. As trust in the organisation and trust in co-workers were positively related, it can be expected that greater levels of trust in co-workers can result in trust in the organisation. Studies have suggested that trust in one's co-workers can be significantly linked to organisational citizenship behaviour (Dar, 2010; Settoon \& Mossholder, 2002).

Contrary to studies that have found a positive relationship between trust in the supervisor and organisational citizenship behaviour (Colquitt, Scott, \& LePine, 2007; Goodwin, Whittington, Murray, \& Nichols, 2011), the results of the present study indicate an insignificant relationship between these constructs. A possible explanation for this may be that health care employees do not necessarily work closely with management, especially in the nursing profession. According to Goldblatt, Granot, Admi and Drach-Zahavy (2008), a shift leader - who is not regarded as a 'manager' but rather as a co-worker - is chosen to take responsibility for shifts. Consequently, when the employees completed the questionnaires, they might have regarded the shift leader as a co-worker rather than a supervisor, resulting in an insignificant relation between trust in the supervisor and organisational citizenship behaviour.

Based on the results, authentic leadership was not found to be a significant predictor of organisational citizenship behaviour. This finding contradicts previous research which found that followers are likely to reciprocate their leader's supportiveness by engaging in extra-role behaviours (Dannhauser, 2007; Piccolo, Greenbaum, Den Hartog, \& Folger, 2010; Tapara, 2011; Xiong \& Fang, 2014). In considering the current sample, it might be expected that, as public health care employees are in a helping profession, their engagement in extra-role behaviours might not be influenced by leadership practices, but rather by a willingness to help patients irrespective of whether effective leadership practices are in place. As the public health care sector is being faced with many challenges (George et al., 2013), the positive organisational culture - as stipulated in the conceptualisation of authentic leadership - might not be true for this industry at present (Stander et al., 2015). As a result, employees might not have regarded authentic leadership as an important contributor to their willingness to perform extra-role behaviours.

The findings of the study indicate that authentic leadership had a significant indirect effect on organisational citizenship behaviour via both trust in the organisation and trust in coworkers. However, authentic leadership did not significantly influence organisational citizenship behaviour via trust in the immediate supervisor. As a result, authentic leadership 
influences trust in the organisation and trust in co-workers, which then influence employees' willingness to exert additional effort. Previous studies have found that trust in general mediates the relationship between employee attitudes and/or behaviours (Clapp-Smith et al., 2009; Hassan \& Ahmed, 2011). As such, it is possible for trust to indirectly affect the relationship between authentic leadership and other follower outcomes as well (Agote Errazquin, 2013). A possible explanation of why trust in the immediate supervisor might not have played a role in this relationship might be attributed to the fact that managers do not work closely to helping professionals and do not work shifts. Instead, a shift leader (in the form of a co-worker) is appointed for different shifts (Goodwin et al., 2011).

These findings are in line with the SET; fair treatment of others leads to a reciprocal exchange which can facilitate positive individual and/or organisational outcomes (Aryee et al., 2002; Blau, 1964). Perceiving a leader as authentic can thus result in perceptions of the organisation and co-workers as trustworthy, resulting in additional effort. In this regard, open, trusting and transparent relationships between the leader and subordinates might enhance consistency between perceptions of the organisation and the organisation's 'actions' (because the leader is a representative of the organisation). The leader may also, through role modelling and personal identification, encourage transparent relationships between co-workers (Avolio et al., 2004), enhancing consistency between perceptions of the coworkers and the co-workers' 'actions'. Employees who believe that they are treated fairly and are supported by their organisation and co-workers are more likely to do more work than expected of them, reciprocating the support they receive. Based on the fact that only trust in the organisation and trust in co-workers indirectly affected organisational citizenship behaviour, the same reasoning applies with regard to the perception of a shift leader as a co-worker instead of a manager (Goldblatt et al., 2008). Trust in the organisation's indirect effect on the relationship between authentic leadership and organisational citizenship behaviour might also be because of the fact that employees working in health care are likely to identify with their organisation as it focuses on helping others.

Finally, the results indicated that trust in the organisation had a stronger indirect effect on the relationship between authentic leadership and organisational citizenship behaviour. This might indicate that if employees trust their organisation to recognise their work and to reward them for their skills and abilities (Ferres, 2003), they might be likely to work harder than what is expected of them in the hope that the organisation will recognise this. Trust in the organisation also focuses on the employees' belief in the organisation to be sustainable and effective (Ferres \& Travaglione, 2003). This might indicate that employees are willing to exert extra effort to contribute to the viability and success of the organisation. If employees therefore feel that their organisation cares for them and recognises their efforts, they will be more willing to go the 'extra mile' irrespective of the challenges they are faced with in this sector (Avolio et al., 2004; Stander et al., 2015).

\section{Limitations and recommendations for future studies}

The study had several limitations which should be taken into consideration when interpreting the current results. Firstly, the study was cross-sectional in nature meaning data were collected at a single point in time. Although causal inferences cannot be made about the constructs, it may be possible that reciprocal relationships may exist, but that they are not captured in cross-sectional designs (Levin, 2006). In future, the constructs may be used for longitudinal studies. The questionnaires used were self-report measures which might result in common method variance where correlations between predictors and outcomes are magnified when only a single data source is used (Podsakoff, MacKenzie, Lee, \& Podsakoff, 2003; Richardson, Simmering, \& Sturman, 2009). A future recommendation is to use multi-rater methods such as in-depth interviews. This study was limited to the public health care sector's employees. A recommendation for future research is to conduct the study on employees in the private health care sector as well, to facilitate comparative studies. Future studies can further benefit by utilising different samples to determine if these factor structures and relationships are unique to this sample or whether they can be generalised.

Finally, two of the measuring instruments in the current study (ALI and WTS) have not been developed in the South African context. This may be a possible explanation behind the poor model fit of some of the scales and necessitated model improvement strategies (e.g. deleting items, correlating error variances and specifying constructs as unidimensional). A recommendation for future research is to conduct validation studies for both these measuring instruments.

\section{Implications for management}

Authentic leadership, workplace trust and organisational citizenship behaviour play a critical role in the public health care sector. The lack of resources, staff shortages, distrust in leadership and financial constraints of public health care institutions are likely to decrease public health care employees' willingness to trust in the organisation, supervisors and co- workers; thereby negatively influencing their willingness to go the 'extra mile'. This is important as research has found that if helping behaviours such as organisational citizenship behaviour in health care are encouraged, employees and organisations are more likely to be more productive and flourish (Gilbert, Laschinger, \& Leiter, 2010). This can have a positive impact on the reputation of public health care facilities. Public health care leaders and management can therefore strive to develop innovative interventions to promote positive employee attitudes and behaviours (Gilbert et al., 2010) to facilitate trust and to enable 
organisations and employees to remain viable in delivering quality health care services.

Leadership development interventions may be conducted to improve managerial skills such as establishing mutually beneficial exchange relationships with employees and building trust (Davies, Wong, \& Laschinger, 2011). In addition, the four factors of authentic leadership can be developed, including self-awareness, relational transparency, balanced processing and an internalised moral perspective. These factors can be advanced by developing leaders' emotional intelligence and by means of coaching. Interventions can further be structured to allow managers to work more closely with employees and to be more authentic in their actions, subsequently resulting in trusting behaviours and, eventually, organisational citizenship behaviour. Other possible interventions to enhance trust in the organisation and trust in the co-worker are to engage in team building exercises and creating a more reliable organisational climate. This climate can be created by empowering employees to take part in decision-making, openly sharing information and being ethical. These are all characteristics of the authentic leader.

With the exception of leadership development, other interventions can also be proposed to particularly enhance trust in the organisation and trust in co-workers. With regard to trust in the organisation, management and executives as representatives of the organisation can be more valuedriven and subsequently live according to organisational values. The organisational climate can also be developed to include interventions aimed at enhancing fair organisational processes and creating a supporting work environment.

\section{Conclusion}

The results of this study support the imperative role of authentic leadership and workplace trust in explaining organisational citizenship behaviour. Although authentic leadership did not directly influence organisational citizenship behaviour, authentic leadership still influenced organisational citizenship behaviour indirectly via trust in the organisation and trust in the co-worker. Trust in the organisation made the most significant impact. These findings indicate that to get employees to go the 'extra mile', leaders need to display genuineness which results in a greater employee identification with the organisation and a greater degree of trust in their co-workers.

\section{Acknowledgements Competing interests}

The authors declare that they have no financial or personal relationships which may have inappropriately influenced them in writing this article.

\section{Authors' contributions}

L.C. analysed the collected data and wrote the manuscript. L.v.d.V. and M.W.S. supervised the study in the form of providing feedback on the manuscript. L.v.d.V. also assisted in collecting the data used in the study.

\section{References}

Al-Sharafi, H., \& Rajiani, I. (2013). Promoting organizational citizenship behavior among employees - The role of leadership practices. International Journal of Business and Management, 8(6), 47-54. http://dx.doi.org/10.5539/ijbm.v8n6p47

Altuntas, S., \& Baykal, U. (2010). Relationship between nurses' organizational trust levels and their organizational citizenship behaviors. Journal of Nursing Scholarship,42(2), 186-194. http://dx.doi.org/10.1111/j.1547-5069.2010.01347.x

Aryee, S., Budhwar, P.S., \& Chen, Z.X. (2002). Trust as a mediator of the relationship between organizational justice and work outcomes: Test of social exchange model. Journal of Organizational Behavior, 23(3), 267-285. http://dx.doi. org/10.1002/job.138

Avolio, B.J., \& Gardner, W.L. (2005). Authentic leadership development: Getting to the roots of positive forms of leadership. The Leadership Quarterly, 16, 315-338. http://dx.doi.org/10.1016/j.leaqua.2005.03.001

Avolio, B.J., Gardner, W.L., Walumbwa, F.O., Luthans, F., \& May, D.R. (2004). Unlocking the mask: A look at the process by which authentic leaders impact follower attitudes and behaviors. The Leadership Quarterly, 15, 801-823. http://dx.doi. org/10.1016/j.leaqua.2004.09.003

Avolio, B.J., \& Walumbwa, F.O. (2014). Authentic leadership theory, research and practice: Steps taken and steps that remain. In D.V. Day (Ed.), The Oxford handbook of leadership and organizations (pp. 331-356). New York: Oxford University Press.

Bakker, A.B., Demerouti, E., De Boer, E., \& Schaufeli, W.B. (2003). Job demands and job resources as predictors of absence duration and frequency. Journal of Vocationa Behaviour, 62, 341-356. http://dx.doi.org/10.1016/S0001-8791(02)00030-1

Bamford, M., Wong, C.A., \& Laschinger, H. (2013). The influence of authentic leadership and areas of worklife on work engagement of registered nurses.
Journal of Nursing Management, 21, 529-540. http://dx.doi.org/10.1111/j. 1365-2834.2012.01399.x

Barnard, A., \& Simbhoo, N. (2014). South African managers in public service: On being authentic. International Journal of Qualitative Studies on Health and Well-being, 9, 1-13. http://dx.doi.org/10.3402/qhw.v9.20630

Bass, B.M. (1990). From transactional to transformational leadership: Learning to share the vision. Organizational Dynamics, 18(3), 19-31. http://dx.doi.org/10. 1016/0090-2616(90)90061-S

Bass, B.M., \& Avolio, B.J. (1993). Transformational leadership: A response to critiques. In M.M. Chemers \& R. Ayman (Eds.), Leadership theory and research: Perspectives and directions (pp. 49-80). San Diego, CA: Academic Press.

Beal III, L., Stavros, J.M., \& Cole, M.L. (2013). Effect of psychological capital and resistance to change on organisational citizenship behaviour. South African Journal of Industrial Psychology, 39(2), 1-11. http://dx.doi.org/10.4102/sajip. v39i2.1136

Beddoes-Jones, F., \& Swailes, S. (2015). Authentic leadership: Development of a new three pillar model. Strategic Human Resources Review, 14(3), 94-99. http://dx. doi.org/10.1108/SHR-04-2015-0032

Benatar, S.R. (2013). The challenges of health disparities in South Africa. South African Medical Journal, 103(3), 154-155. http://dx.doi.org/10.7196/SAMJ.6622

Bester, J., Stander, M.W., \& Van Zyl, L.E. (2015). Leadership empowering behaviour, psychological empowerment, organisational citizenship behaviours and turnover intention in a manufacturing division. South African Journal of Industria Psychology, 41(1), 1-14. http://dx.doi.org/10.4102/sajip.v41i1.1215

Blau, P.M. (1964). Exchange and power in social life. New York: John Wiley \& Sons Inc.

Byrne, B.M. (2012). Structural equation modeling with Mplus: Basic concepts, applications and programming. New York: Routledge Taylor \& Francis Group.

Chen, C.V., Wang, S., Chang, W., \& Hu, C. (2008). The effect of leader-member exchange, trust, supervisor support on organizational citizenship behavior in nurses. Journal of Nursing Research, 16(4), 321-328. http://dx.doi.org/10. 1097/01.JNR.0000387319.28010.5e

Cho, Y.J., \& Park, H. (2011). Exploring the relationships among trust, employee satisfaction, and organizational commitment. Public Management Review, 13(4) 551-573. http://dx.doi.org/10.1080/14719037.2010.525033

Christian, C.S., \& Crisp, N. (2012). Management in the South African public health sector: An x-inefficiency perspective. Development Southern Africa, 29(5), 725737. http://dx.doi.org/10.1080/0376835X.2012.730972

Clapp-Smith, R., Vogelsang, G.R., \& Avey, J.B. (2009). Authentic leadership and positive psychological capital: The mediating role of trust at the group level of analysis. Journal of Leadership \& Organizational Studies, 15(3), 227-240. http://dx.doi. org/10.1177/1548051808326596

Colquitt, J.A., Scott, B.A., \& LePine, J.A. (2007). Trust, trustworthiness, and trust propensity: A meta-analytic test of their unique relationships with risk taking and job performance. Journal of Applied Psychology, 92, 909-927. http://dx.doi. org/10.1037/0021-9010.92.4.909

Dannhauser, Z. (2007). The relationship between servant leadership, follower trust, team commitment and unit effectiveness. Doctoral dissertation. South Africa: University of Stellenbosch. Retrieved August 20, 2015, from http://webcache. googleusercontent.com/search?q=cache:w-_ctpCOs0AJ:scholar.sun.ac.za/handle /10019.1/1365+\&cd=1\&hl=en\&ct=clnk\&gl=za

Dar, O.L. (2010). Trust in co-workers and employee behaviours at work. International Review of Business Research Papers, 6(1), 194-204. 
Dash, S., \& Pradhan, R.K. (2014). Determinants and consequences of organizational citizenship behavior: A theoretical framework for Indian manufacturing organisations. International Journal of Business and Management Invention, 3(1) 17-27. Retrieved July 14, 2015, from http://www.ijbmi.org/papers/Vol(3)1/ Version-1/C03101017027.pdf

Datta, B. (2015). Assessing the effectiveness of authentic leadership. Internationa Journal of Leadership Studies, 9(1), 62-75. Retrieved July 1, 2015, from http:// www.regent.edu/acad/global/publications/ijls/new/vol9iss1/2-IJLS.pdf

Davies, A.D., Wong, C.A., \& Laschinger, H. (2011). Nurses' participation in persona knowledge transfer: The role of leader-member exchange (LMX) and structura empowerment. Journal of Nursing Management, 19, 632-643. http://dx.doi. org/10.1111/j.1365-2834.2011.01269.x

Demerouti, E., Bakker, A.B., Nachreiner, F., \& Schaufeli, W.B. (2001). The job demandsresources model of burnout. Journal of Applied Psychology, 86(3), 499-512. $\mathrm{http}: / / \mathrm{dx}$.doi.org/10.1037//0021-9010.86.3.499

Diedericks, E. (2012). Flourishing of employees in the information technology industry in South Africa. Doctoral dissertation. Vanderbijlpark, South Africa: North-West University. Retrieved April 06, 2015, from http://dspace.nwu.ac.za/bitstream/ handle/10394/10278/Diedericks E.pdf?sequence $=1$

Du Plessis, M. (2014). The relationship between authentic leadership, psychological capital, followership and work engagement. Doctoral dissertation. Western Cape, South Africa: University of the Western Cape.

Du Plessis, M., Wakelin, Z., \& Nel, P. (2015). The influence of emotional intelligence and trust on servant leadership. South African Journal of Industrial Psychology, 41(1), 1-9. http://dx.doi.org/10.4102/sajip.v41i1.1133

Engelbrecht, A.S., Heine, G., \& Mahembe, B. (2014). The influence of ethical leadership on trust and work engagement: An exploratory study. South African Journal of Industrial Psychology, 40(1), 1-9. http://dx.doi.org/10.4102/sajip.v40i1.1210

Errazquin, L.A. (2013). Authentic leadership, trust and followers' emotions: The experience of HRMs during organizational change processes. Azkoaga, 16, 123-148.

Ferres, N. (2003). The development and validation of the Workplace Trust Survey (WTS): Combining qualitative and quantitative methodologies. Unpublished master's thesis, University of Newcastle, Australia.

Ferres, N., \& Travaglione, T. (2003). The development and validation of the workplace trust survey (WTS): Combining qualitative and quantitative methodologies. Paper presented at APROS, Mexico.

Galford, R., \& Drapeau, A.S. (2003). The enemies of trust. Harvard Business Review, 81(2), 88-95.

Gardner, W.L., Avolio, B.J., Luthans, F., May, D.R., \& Walumbwa, F. (2005). 'Can you see the real me?' A self-based model of authentic leader and follower development. The Leadership Quarterly, 16, 343-372. http://dx.doi.org/10.1016/j. leaqua.2005.03.003

Gardner, W.L., Cogliser, C.C., Davis, K.M., \& Dickens, M.P. (2011). Authentic leadership A review of the literature and research agenda. The Leadership Quarterly, 22, 1120-1145. http://dx.doi.org/10.1016/j.leaqua.2011.09.007

George, G., Atujuna, M., \& Gow, J. (2013). Migration of South African health workers: The extent to which financial considerations influence internal flows and external movements. BMC Health Services Research, 13(1), 297-310. http://dx.doi.org/10. 1186/1472-6963-13-297

Gilbert, S., Laschinger, H.K.S., \& Leiter, M. (2010). The mediating effect of burnout on the relationship between structural empowerment and organizational citizenship behaviors. Journal of Nursing Management, 18, 339-348. http://dx.doi.org/10. 1111/j.1365-2834.2010.01074.x

Goldblatt, H., Granot, M., Admi, H., \& Drach-Zahavy, A. (2008). The experience of being a shift-leader in a hospital ward. Journal of Advanced Nursing, 63(1), 45-53. $\mathrm{http}: / / \mathrm{dx}$.doi.org/10.1111/j.1365-2648.2008.04650.x

Goodwin, V.L., Whittington, J.L., Murray, B., \& Nichols, T. (2011). Moderator or mediator? Examining the role of trust in the transformational leadership paradigm. Journal of Managerial Issues, 23(4), 409-425.

Hair, J.F., Black, W.C., Babin, B.J., \& Andersen, R.E. (2010). Multivariate data analysis: A global perspective. Upper Saddle River, NJ: Pearson Education Press.

Halbesleben, J.R.B., \& Wheeler, A.R. (2012). To invest or not? The role of co-worker support and trust in daily reciprocal gain spirals of helping behavior. Journal of Management, 41(6), 1628-1650. http://dx.doi.org/10.1177/0149206312455246

Harter, J.K., Schmidt, F.L., \& Keyes, C.L.M. (2003). Well-being in the workplace and its relationship to business outcomes: A review of the Gallup studies. In C.L.M. Keyes, \& J. Haidt (Eds.), Flourishing: Positive psychology and the life well-lived (pp. 205224). Washington, DC: American Psychological Association.

Hartog, D.N.D., Shippers, M.C., \& Koopman, P.L. (2002). The impact of leader behaviour on trust in management and co-workers. South African Journal of Industrial Psychology, 28(4), 29-34.

Hassan, A., \& Ahmed, F. (2011). Authentic leadership, trust and work engagement International Journal of Human and Social Sciences, 6(3), 164-170. Retrieved April 10, 2015, from http://ejournal.narotama.ac.id/files/v6-3-24.pdf

Health Systems Trust. (2013). South African Health Review 2012/2013 [Adobe Digital Editions Version]. Retrieved March 28, 2015, from http://www.health-e.org.za/ wp-content/uploads/2013/04/SAHR2012_13_lowres_1.pdf

Heyns, M., \& Rothmann, S. (2015). Dimensionality of trust: An analysis of the relations between propensity, trustworthiness and trust. South African Journal of Industria Psychology, 41(1), 1-12. http://dx.doi.org/10.4102/sajip.v41i1.1263

Hsieh, C.C., \& Wang, D.S. (2015). Does supervisor-perceived authentic leadership influence employee work engagement through employee-perceived authentic leadership and employee trust? International Journal of Human Resource Management, 1-22. http://dx.doi.org/10.1080/09585192.2015.1025234
Hu, L., \& Bentler, P.M. (1999). Cut off criteria for fit indexes in covariance structure analysis: Conventional criteria versus new alternatives. Structural Equation Modeling, 6(1), 1-55. http://dx.doi.org/10.1080/10705519909540118

IBM Corporation. (2013). IBM SPSS Statistics for Windows (Version 22.0). Armonk, NY: IBM Corporation.

Ilies, R., Morgeson, F.P., \& Nahrgang, J.D. (2005). Authentic leadership and eudaimonic well-being: Understanding leader-follower outcomes. The Leadership Quarterly, 16, 373-394. http://dx.doi.org/10.1016/j.leaqua.2005.03.005

James, L.J. (2011). The relationship between perceived organisational support and workplace trust: An exploratory study. Master's thesis. Western Cape, South Africa: University of the Western Cape. Retrieved August 2, 2015, from http://etd. uwc.ac.za/xmlui/bitstream/handle/11394/3188/James_MCOM_2011. pdf?sequence $=1$

Kelloway, E.K. (2015). Using Mplus for structural equation modeling: A researcher's guide (2nd edn.). London, UK: Sage.

Khan, S.N. (2010). Impact of authentic leaders on organization performance International Journal of Business and Management, 5(12), 167-172. Retrieved August 20, 2015, from http://www.ccsenet.org/journal/index.php/ijbm/article/ viewFile/6742/6343

Kline, R.B. (2011). Principles and practice of structural equation modeling (3rd edn.). New York: The Guilford Press.

Lencioni, P. (2005). Overcoming the five dysfunctions of a team: A field guide for leaders, managers, and facilitators. San Francisco, CA: Jossey-Bass.

Levin, K.A. (2006). Study design III: Cross-sectional studies. Evidence-based Dentistry, 7, 24-25. http://dx.doi.org/10.1038/sj.ebd.6400375

Maximo, N. (2015). Authentic leadership, trust and work engagement: The mediating role of psychological safety. Master's dissertation. Retrieved September 25, 2015, from http://hdl.handle.net/10394/16533

Mazutis, D., \& Slawinski, N. (2007). The art of conversation: How authentic leaders influence organizational learning. Learning Fusion, 662-675. http://dx.doi.org/ 10.1.1.321.3942

Men, L.R., \& Stacks, D. (2014). The effects of authentic leadership on strategic internal communication and employee-organization relationships. Journal of Public Relations Research, 26(4), 301-324. http://dx.doi.org/10.1080/1062726X.2014. 908720

Mokgele, K.R.F., \& Rothmann, S. (2014). A structural model of student well-being South African Journal of Psychology, 44(4), 514-527. http://dx.doi.org/10. $1177 / 0081246314541589$

Muthén, L.K., \& Muthén, B.O. (1998-2012). Mplus user's guide (7th edn.). Los Angeles, CA: Muthén \& Muthén. Retrieved from http://www.statmodel.com/ download/usersguide/Mplus\%20user\%20guide\%20Ver_7_r3_web.pdf

Neider, L.L., \& Schriesheim, C.A. (2011). The Authentic Leadership Inventory (ALI): Development and empirical tests. The Leadership Quarterly, 22(6), 1146-1164. http://dx.doi.org/10.1016/j.leaqua.2011.09.008

O'Reilly, C.A., Caldwell, D.F., Chatman, J.A., Lapiz, M., \& Self, W. (2010). How leadership matters: The effects of leaders' alignment on strategy implementation. The Leadership Quarterly, 21(1), 104-113. http://dx.doi.org/10.1016/j.leaqua.2009. 10.008

Okanga, B., \& Drotskie, A. (2015). Integrated strategic healthcare management control techniques for effective performance of the South African public healthcare system. Journal of Contemporary Management, 12,61-84. Retrieved July 14 2015, from http://reference.sabinet.co.za/webx/access/electronic journals/ jcman/jcman_v12_a4.pdf

Onorato, M., \& Zhu, J. (2014). An empirical study on the relationships between authentic leadership and organizational trust by industry segment. SAM Advanced Management Journal, 79(1), 26-39.

Organ, D.W. (1997). Organizational citizenship behavior: It's construct clean-up time. Human Performance, 10(2), 85-97. http://dx.doi.org/10.1207/s15327043hup 10022

Organ, D.W., \& Paine, J.B. (1999). A new kind of performance for industrial and organizational psychology: Recent contributions to the study of organizational citizenship behavior. International Review of Industrial and Organizational Psychology, 14, 337-368. http://dx.doi.org/10.1023/A:1007713412780

Paliszkiewicz, J., Koohang, A., \& Nord, J.H. (2014). Management trust, organizational trust, and organizational performance: Empirical validation of an instrument. Online Journal of Applied Knowledge Management, 2(1), 28-39.

Penger, S., \& Cěrne, M. (2014). Authentic leadership, employees' job satisfaction, and work engagement: A hierarchical linear modelling approach. Economic ResearchEkonomska Istraživanja, 27(1), 508-526. http://dx.doi.org/10.1080/1331677X. 2014.974340

Piccolo, R.F., Greenbaum, R., Den Hartog, D.N., \& Folger, R. (2010). The relationship between ethical leadership and core job characteristics. Journal of Organizationa Behavior, 31(2-3), 259-278. http://dx.doi.org/10.1002/job.627

Podsakoff, P.M., MacKenzie, S.B., Lee, J.Y., \& Podsakoff, N.P. (2003). Common method biases in behavioral research: A critical review of the literature and recommended remedies. Journal of Applied Psychology, 88(5), 879-903. http://dx.doi.org/10. 1037/0021-9010.88.5.879

Preacher, K.J., \& Kelley, K. (2011). Effect sizes for mediation models: Quantitative strategies for communicating indirect effects. Psychological Methods, 16(2), 93115. http://dx.doi.org/10.1037/a0022658

Pues, C., Wesche, J.S., Streicher, B., Braun, S., \& Frey, D. (2012). Authentic leadership: An empirical test of its antecedents, consequences, and mediating mechanisms. Journal of Business Ethics, 107, 331-348. http://dx.doi.org/10.1007/s10551-011- 
Raykov, T. (2009). Evaluation of scale reliability for unidimensional measures using latent variable modelling. Measurement and Evaluation in Counseling \& Development, 42(3), 223-232. http://dx.doi.org/10.1177/0748175609344096

Rego, A., Vitória, A., Magalhães, A., Ribeiro, N., \& Cunha, M.G. (2013). Are authentic leaders associated with more virtuous, committed and potent teams? The Leadership Quarterly, 24(1), 61-79. http://dx.doi.org/10.1016/j.leaqua.2012.08.002

Richardson, H.A., Simmering, M.J., \& Sturman, M.C. (2009). A tale of three paradigms: Examining post hoc statistical techniques for detection and correction of common method variance. Organizational Research Methods, 12, 687-694. http://dx.doi. org/10.1177/1094428109332834

Rothmann, S. (2010). Unpublished research report: The reliability and validity of measuring instruments of happiness in the Southern African context. Vanderbijlpark, South Africa: North-West University.

Ryan, R.M., \& Deci, E.L. (2003). On assimilating identities to the self: A selfdetermination theory perspective on internalization and integrity within cultures. In M.R. Leary \& J.P. Tangney (Eds.), Handbook of self and identity (pp. 253-272). New York: Guilford Publishers.

Satorra, A., \& Bentler, P.M. (1999). A scaled difference chi-square test statistic for moment structure analysis [Adobe Digital Editions Version]. Retrieved July 28 2015, from http://escholarship.org/uc/item/23c604tb

Schlechter, A.F., \& Strauss, J.J. (2008). Leader emotional intelligence, transformationa leadership, trust and team commitment: Testing a model within a team context. South African Journal of Industrial Psychology, 34(1), 42-53. http://dx.doi. org/10.4102/sajip.v34i1.418

Schoeman, J.D. (2012). The relationship between work place well-being, psychological capital and work place trust. Doctoral dissertation. South Africa: Nelson Mandela Metropolitan University. Retrieved July 15, 2015, from http://contentpro.seals. ac.za/iii/cpro/app?id=8615355919551170\&itemld=1013044\&lang=eng\&service= blob\&suite=def

Settoon, R., \& Mossholder, K. (2002). Relationship quality and relationship context as antecedents of person- and task-focused interpersonal citizenship behavior. Journal of Applied Psychology, 87(2), 255-267. http://dx.doi.org/10.1037/0021 9010.87.2.255

Shamir, B., House, R.J., \& Arthur, M.B. (1993). The motivational effects of charismatic leadership: A self-concept based theory. Organization Science, 577-594. http:// dx.doi.org/10.1287/orsc.4.4.577

South Africa. Department of Health. (2011). National core standards for health establishments in South Africa. Retrieved April 20, 2015, from http://www. sarrahsouthafrica.org/LinkClick.aspx?fileticket=YnbSHfR8S6Q

South Africa. National Planning Commission (2011) National development plan - Vision for 2030 [Adobe Digital Editions Version]. Retrieved April 20, 2015, from http:// www.poa.gov.za/news/Documents/NPC\%20National\%20Development $\%$ 20 Plan $\% 20$ Vision $\% 202030 \% 20$-lo-res.pdf
Stander, F.W., De Beer, L.T., \& Stander, M.W. (2015). Authentic leadership as a source of optimism, trust in the organisation and work engagement in the public health care sector. South African Journal of Human Resource Management, 13(1), 1-12. http://dx.doi.org/10.4102/sajhrm.v13i1.675

Stone, A.G., Russell, R.F., \& Patterson, K. (2004). Transformational versus servant leadership: A difference in leader focus. Leadership and Organization Development Journal, 25(4), 349-361. http://dx.doi.org/10.1108/01437730 410538671

Tapara, P.L. (2011). Authentic leadership: Organisational outcomes and leader and follower development. Master's thesis. Albany, New Zealand: Massey University. Retrieved March 12, 2015, from http://hdl.handle.net/10179/2858

Treviño, L.K., \& Brown, M.E. (2004). The role of leaders in influencing unethical behavior in the workplace [Adobe Digital Editions Version]. Retrieved August 20, 2015, from http://www.corwin.com/upm-data/4910_Kidwell_Chapter_3.pdf

Walumbwa, F.O., Avolio, B.J., Gardner, W.L., Wernsing, T.S., \& Peterson, S.J. (2008) Authentic leadership: Development and validation of a theory-based measure. Journal of Management, 34(1), 89-126. http://dx.doi.org/10.1177/014920 6307308913

Walumbwa, F.O., Christensen, A.L., \& Hailey, F. (2011). Authentic leadership and the knowledge economy: Sustaining motivation and trust among knowledge workers. Organizational Dynamics, 40, 110-118. http://dx.doi.org/10.1016/j.orgdyn.2011. 01.005

Wang, D.S., \& Hsieh, C.C. (2013). The effect of authentic leadership on employee trus and employee engagement. Social Behavior and Personality: An International Journal, 41(4), 613-624. http://dx.doi.org/10.2224/sbp.2013.41.4.613

Wang, J., \& Wang, X. (2012). Structural equation modeling: Applications using Mplus. Chichester, United Kingdom: Wiley \& Sons Inc.

Wong, C.A., Laschinger, H., \& Cummings, G.G. (2010). Authentic leadership and nurses' voice behaviour and perceptions of care quality. Journal of Nursing Management, 18, 889-900. http://dx.doi.org/10.1111/j.1365-2834.2010. 01113.x

Wong, Y., Wong, C. \& Ngo, H. (2012). The effects of trust in organisations and perceived organisational support on organisational citizenship behaviour: A test of three competing models. The International Journal of Human Resource Management, 23(2), 2478-293. http://dx.doi.org/10.1080/09585192.2011. 610966

Xiong, H-B., \& Fang, P. (2014). Authentic leadership, collective efficacy, and group performance: An empirical study in China. Social Behaviour and Personality, 42(6), 921-932. http://dx.doi.org/10.2224/sbp.2014.42.6.921

Zbierowski, P., \& Góra, K. (2014). Positive leadership: Its nature, antecedents and consequences. Journal of Positive Management, 5(1), 85-99. http://dx.doi. org/10.12775/JPM.2014.008 